\title{
JOURNAL OF PHILOSOPHICAL STUDIES
}




\section{JOURNAL OF PHILOSOPHICAL STUDIES}

EDITED BY

SYDNEY E. HOOPER

WITH THE ASSISTANCE OF

S. ALEXANDER WILIIAM BROWN

M. GINSBERG

G. DAWES HICKS JULIAN S. HUXLEY
F. B. JEVONS

HAROLD J. LASKI

A. D. LINDSAY

JOHN S. MACKENZIE

J. H. MUIRHEAD
BERTRAND RUSSELL

G. F. STOUT

A. E. TAYLOR

J. ARTHUR THOMSON CLEMENT C. J. WEBB

\section{VOL. IV.-I929}

\section{LONDON :}

MACMILLAN \& CO., LIMITED,

ST. MARTIN'S STREET, W.C. 2

I929 
PRINTED IN GREAT BRITAIN BY UNWIN BROTHERS LIMITED LONDON AND WOKING 


\section{CONTENTS OF VOLUME IV}

EDITORIAL

\section{ARTICLES.}

Alexander, S.-Philosophy and Art - - - - - - - $\quad 157$

BARRAClough, G.-The Basis of Politics: Aristotle and the Scientists - $\quad$ - 490

BRIghtMAN, EDGAR S.-The Importance of Being Conscious - - - 497

BROWN, WilliaM.-Religion and Science - - - - - $\quad$ - 39

BURNS, C. DeIISLE. - The Philosophy of Social Life-

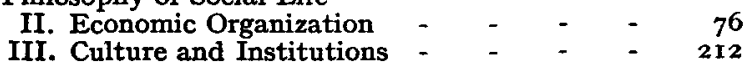

IV. Man and Society - - - - - $\quad-367$

Campion, George G.-Meaning and Error - - - - - - - 241

CARR, H. WILdON.-Some Reflections on the New Cosmogony - - $\quad$ - 346

Collingwood, R. G.-Form and Content in Art - - - - - 332

Dr BURGH, W. G.-Gentile's Philosophy of the Spirit - $\quad$ - $\quad$ - $\quad$ - 3

Ewisg, A. C.-The Idea of Cause - - - - - - - - 453

FLOWER, J. CYRIL.-Emotion, Feeling and Religion - - - - $\quad-{ }_{192}$

GrNSBERG, MORRIs.-Leonard Trelawny Hobhouse - - - - - 442

Gunn, J. AleXandir.-The Problem of Time - - - - - $\quad$ - 180

JOAD, C. E. M.-The One and the Many - - - - $\quad-\quad-\quad-\quad 87$

Mind and Body - - - - $\quad-\quad-\quad-\quad-\quad-\quad 225$

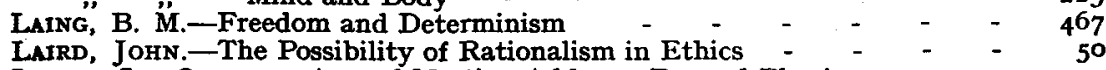

LODGE, Str OLIVER.-Annual Meeting Address: Beyond Physics - $\quad$ - 515

LosSKY, N.-The Metaphysics of the Stoics - - - - - - 481

MACMURRAY, J.-The Unity of Modern Problems - - - - - $\quad$ - 162

Morgan, C. Lloyd.-The Case for Emergent Evolution - - - - - - $\quad 23$

Ross, W. D.-The Ethics of Punishment - - - - - - - 205

RUSSELL, LeONard J.-Science in Practice - - - - - - - - 356

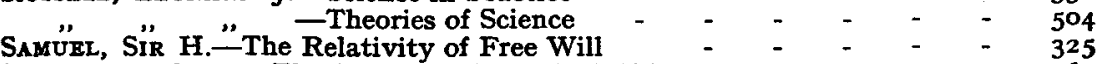

Stapledon, Otaf.-The Location of Physical Objects - - - $\quad$ - 64

Stocks, J. L.-Moral Values - - - - - - - - 299

WALKRR, L. J.-The Physical World - - - - - - - 314

\section{PHILOSOPHICAL SURVEYS.}

Philosophy in France.-Stanley Keeling PuIlosophy IN Germany.-Helen Knight

Phizosophy in Italy.-Professor G. de Ruggiero Philosophy in Russia.- Natalie A. Duddington 


\section{CONTENTS}

\section{NEW BOOKS.}

BaIley, C.-The Greek Atomists and Epicurus (J. L. Stocks) - - Bevan, E.-Sibyls and Seers, a Survey of Some Ancient Theories of Revelation and Inspiration (A. E. Garvie)

Boodre, J. E.-Cosmic Evolution (Michael B. Foster)

Broad, C. D.-John McTaggart Ellis McTaggart, I866-I925 (S. V. Keeling)

BrosNaM, W. J.-God Infinite and Reason: Concerning the Attributes of God (L. J. W.)

Brown, WILliaM.-Science and Personality (L. J. Russell) - - - -

Bruhl, L. L. (Translator: Clare, L. A.).-The "Soul" of the Primitive (B. Malinowski)

CARR, H. WILdoN.-Leibniz (John Laird)

CARRITT, E. F.-The Theory of Morals: An Introduction to Ethical Philosophy (J. L, Stocks)

Chance, Roger.-Until Philo: - -

Costes, A. -A Sceptical Examination of Contemporary British Philosophy (John Laird)

Constable, F. C. $-\bar{A} \bar{A}(\overline{\mathrm{J}} !$ Laird)

DAshiel,, J. F.-Fundamentals of Objective Psychology (F. Aveling)

DAwson, C.-Progress and Religion: an Historical Enquiry (A. E. Garvie) -

DE HaAN, J. A. B.-Animal Psychology for Biologists (C. Lloyd Morgan) -

DEWEY, J. Experience and Nature(I. J. Russell)

DrxoN, E. T. The Guidance of Conduct (F. Aveling)

Dra KE, D.-The New Morality (J. Laird)

Dresser, H. W. $-A$ History of Modern Philosophy (J. Laird) - - -

Eddington, A. S.-The Nature of the Physical World (Leonard Russell) -

Enitors: Delorme, Ferdinand; Steele, Roberto; Little, A. G.; Withington, E. Opera hactenus inedita Rogeri Baconi. Fasc. VIII. Fasc. IX. (A. E. Taylor)

Elliotr, W. Y.-The Pragmatic Revolt in Politics (J. A. Hobson) - -

FARBer, M.-Phenomenology as a Method and as a Philosophical Discipline (J. W. Harvey)

Grabmand, M. (Translated by Michel, V.).-Thomas Aquinas' His Personalify and Thought (L. J. W.)

Haldane, J. S.-The Sciences and Philosophy (L. J. Russell) - - -

Hemens, F.-Relativity and the Hegelian Philosophy (H. Wallis Chapman) Herzberg, A.-The Psychology of Philosophers (John Laird)

Hirst, E. Wales.-Ethical Love (J. Cyril Flower)

HuXley, Aldous.-Point Counterpoint (L. Collier)

Hyde, LawRËCE,-The Learned Knife (T. E. Jessop)

INGE, W. R.-Plotinus (E. R. Dodds) -

JoAD, C. E. M.-The Meaning of Life (J. E. Turner) - - - - -

Johnson and Strutrers.-Hegel's Science of Logic (John S. Mackenzie) -

Jung, C. G. (Translators: H. G. and C. F. Baynes).-Contributions to Analytical Psychology (R. G. Gordon)

LADD-FrankLIN, C.-Colour and Colour Theories (F. W. Edridge-Green) LEE, A.-Sociality. The Art of Living Together (J. Macmurray) - - LITTLE, A. G.-Roger Bacon (Annual Lecture on a Master Mind) (J. Laird)LODGE, R. C.-Plato's Theory of Ethics (G. C. Field) -

Low, B.-The Unconscious in Action (M. Ginsberg) - _ - - LYMAN, E. W. The Meaning of Selfhood and Faith in Immortality (E. S. Waterhouse)

Mackenzir, J. S. - Fundamental Problems of Life (Michael Oakéshott) ". " -A Manual of Ethics (Olaf Stapledon) - - - McK̈̈́on, RïchaRd. - The Philosophy of Spinoza (I. Levine) - - - - 268

Macran, H. S.-Hegel's Logic of World and Idea (John S. Mackenzie) - $\quad 561$

Marston, W. M.-Emotions of Normal People (F. Aveling) - - - - $\quad$ I38 $^{2}$

MrRedith, J. C. (Translator).-Kant's Critique of Teleological Judgement (A. C. Ewing)

MuLER, N.-The Child in Primitive Society (V. Hazlitt) -

Mulrhead, J. H.-The Use of Philosophy. Californian Addresses (H. J. Paton)

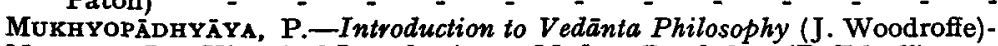
MURPHY, G.-Historical Introduction to Modern Psychology (B. Edgell) -

PAGI

400

I 32

255

122

414

571

$42 \mathrm{I}$

266

142

276

567

I 43

428

407

573

555

426

I 45

I3I

252

26 I

I 29

I 37

413

558

566

575

278

394

394

279

406

277

$56 \mathrm{I}$

28 I

424

147

412

II 7

I 48

142

264

568

561

120

I 45

128

126

419 vi 


\section{CONTENTS}

Murray, Girbert.-The Ordeal of this Generation (W. Arnold-Foster) - $\quad$ PAGE

Patrerson, C. H.-Problems in Logic (S. V. Keeling) - - - - - - 143

PeaR, T. H. - Fitness for Work (F.C. Bartlett) - - - - - - - - 144

PIAGET, J.-The Child's Conception of the World (B. Edgell) - - - - $^{222}$

Pratt, James Bissetr.-The Pilgrimage of Buddhism and a Buddhist Pilgrimage (C. A. F. Rhys Davids) - $\quad-\quad-\quad-\quad-\quad-\quad-\quad-\quad$ - $\quad 274$

Prichard, H. A.-Duty and Interest (W. G. de Burgh) - - - - - 259

Prince, Morton.-Clinical and Experimental Studies in Personality (T. W. Mitchell)

Radmakrishnan, S.-Kalki, or the Future of Civilization (J. S. Mackenzie) " $\quad$ "The Vedänta according to Samkara and Rämänuja " "The Vedänta according to Samkara and Rämänuja

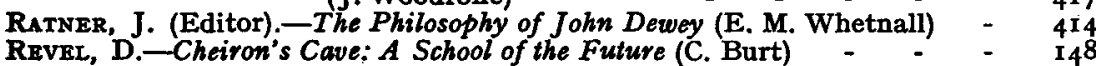

REVEL, D.-Cheiron's Cave: A School of the Future (C. Burt)
RoBIN, L.-Greek Thought and the Origins of the Scientific Spirit (G. C. Field) -

Ro Fin - -

Ross, W. D. (Editor). -The Works of Aristotle (C, M. Gillespie) - $\quad$ - 257

Roth, Leon.-Spinoza (I. Levine) - - - - - - - - $\quad$ - $27^{\circ}$

Russelt, Bhrtrand.-Sceptical Essays (L. S. Stebbing) - - - - $\quad 263$

SchneIDER, H. W.-Making the Fascist State (J. A. Hobson) - - - 405

Scoon, R.-Greek Philosophy before Plato (G. C. Field) - - - - $\quad$ Ix7

Srllars, Roy Woop.-Religion Coming of Age (W. G. de Burgh) - - $\quad 271$

Shastri, P. D.-Essentials of Eastern Philosophy (J. Woodroffe) - - 124

SRINIVASAchari, P. N.-Rämänuja's Idea of the Finite Self (J. Woodroffe) - 4 I9

STAPLEDON, O.-A Modern Theory of Ethics (B. M. Laing) - - -403

Tarrant, D. (Editor).-The Hippias Major, Attributed to Plato (G. C. Field) - - - - - - - - - $\quad-\quad-\quad-\quad$ - II

Urouhart, W. S.-The Vedanta and Modern Thought (J. Woodroffe) - ${ }_{415}$

Wallas, MaY.-Luc de Clapiers: Marquis de Vauvenargues (John Laird) - $\quad 2_{7}^{8}$

WaTT, T. M.-The Intuition of God: an Introduction to the Philosophy of Mysticism (A. E. Garvie)

Werton, James, MonahaN, A. J. (Revised by E. M. Whetnali).-intermediate

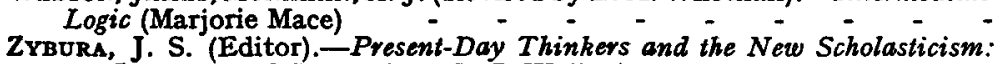
An International Symposium (L. J. Walker)

410

282

136

\section{CORRESPONDENCE.}

Champness, E. A.

Chapman, H. W

Eshlrman; C. $\mathbf{H}$.

Farber, Marvin

HENSON, BERTRAM

JoAD, C. E. M.

Morgan, C. Lloyd

Pailip, A

Stretr, R.

TAYLOR, A. E.

\section{INSTITUTE NOTES.}

Broadcast Talks on Philosophy

Cardiff Centre

Lecture Courses, Lent Term

Liverpool Centre

North Wales Centre

Northumberland and Durham Centre

Evening Meetings: Programme for Lent Term, 1929

Husband, Mrs. Guilliland. Obituary Notice 


\section{CONTENTS}

Russell, Professor Leonard: Titles of Lectures. Lent term, r929 - - - 291 Student Members "At Home" - - - - - $\quad-\quad-\quad-\quad 291,582$

Wireless "Talks" on Philosophy

MISCELLANEOUS.

Bradley, F. H., Posthumous Portrait of - - - - - - - 581

Hobhouse, L. T., Obituary Notice - - - - - - - - - 433

Hobhouse, L. T., Memorial to - - - - $\quad$ - $\quad-\quad-\quad-\quad-547$ 